Forest Ecology and

Management

\title{
Invasive alien trees and water resources in South Africa: case studies of the costs and benefits of management
}

\author{
D.C. Le Maitre ${ }^{\mathrm{a}, *}$, B.W. van Wilgen ${ }^{\mathrm{a}}$, C.M. Gelderblom ${ }^{\mathrm{a}}$, C. Bailey ${ }^{\mathrm{b}}$, \\ R.A. Chapman ${ }^{\mathrm{a}}$, J.A. Nel ${ }^{\mathrm{a}}$ \\ ${ }^{a}$ CSIR Division of Water, Environment and Forestry Technology, P.O. Box 320, Stellenbosch 7599, South Africa \\ ${ }^{\mathrm{b}}$ CSIR Division of Water, Environment and Forestry Technology, P.O. Box 395, Pretoria 0001, South Africa
}

Received 12 April 2000; received in revised form 2 January 2001; accepted 15 January 2001

\begin{abstract}
Invasive alien plants are consumptive water-users, and may have reduced river flows in South Africa by about $6.7 \%$ according to a broad-scale study. An effective programme to bring the invasions under control would cost about US\$ 92 million per year for the next 20 years. This paper reports on studies of four representative catchments (the Sonderend, Keurbooms, Upper Wilge and Sabie-Sand) to assess the impacts and costs of invasions at a scale that is more relevant to managers. Several alien plant species have invaded the catchments. Non-riverine invasions are mainly Pinus and Hakea species in Sonderend and Keurbooms, eucalypts in the Upper Wilge, and pines and scramblers (e.g. Lantana camara) in the Sabie-Sand catchment. Riverine invasions are dominated by Acacia mearnsii and, to a lesser extent, A. dealbata, except in the Sabie-Sand and the lower Sonderend River where Eucalyptus species are important. About $44 \%$ of the Sonderend, 54\% of the Keurbooms, $2 \%$ of the Upper Wilge and $23 \%$ of the Sabie-Sand catchments has been invaded to some degree. The corresponding reductions in the natural river flows attributed to these invasions are about 7.2, 22.1, 6.0 and 9.4\%. If the invasions are not controlled they could potentially spread, and occupy $51,77,70 \%$, respectively, of the first three catchments. At an annual expansion rate of 10-15\% this would take about 13,26 and 63 years, respectively. The invadable areas in the Sabie-Sand catchment are already invaded so invasions will only increase in density. It would take about 26-30 years to reach $100 \%$ canopy cover. The projected flow reductions for the four catchments would increase to 41.5, 95.5, 25.1 and 22.3\%, respectively. The estimated cost of the control programmes to prevent these losses would be about US\$13.2, 9.9, 4.1 and 6.6 million for the Sonderend, Keurbooms, Upper Wilge and Sabie-Sand catchments, respectively. Should the catchments be allowed to become fully invaded before control operations were started, then the costs would rise to US\$ 86.5, 20.5, 278.0 and 11.1 million, respectively. The impacts and costs are significant and are comparable with those calculated independently for other South African catchments. Water is acknowledged to be a key constraint to economic growth in South Africa and there is considerable pressure for efficient and sustainable use of the limited water resources. The projected impacts would justify control programmes aimed at clearing alien invaders for water conservation. (C) 2002 Elsevier Science B.V. All rights reserved.
\end{abstract}

Keywords: Invasions; Resource economics; Forestry; Commercial plantations; Catchment management

\footnotetext{
* Corresponding author. Tel.: +27-21-888-2610; fax: +27-21-888-2693.

E-mail address: dlmaitre@csir.co.za (D.C. Le Maitre).
}

\section{Introduction}

Natural forests in southern Africa are surprisingly limited in their extent. Areas that receive in excess of 
$800 \mathrm{~mm}$ of rainfall annually, at altitudes below $2000 \mathrm{~m}$, are covered by grasslands or shrublands, while similar areas in other parts of the world would support natural forests (Holdridge et al., 1971; Schulze and McGee, 1978). One of the main reasons for this disparity is repeated fires which prevent the establishment of forest species (Moll et al., 1980; Manders, 1990; Manders and Richardson, 1992). In areas which are sheltered from regular fires, forests can and do develop (Geldenhuys, 1994), and forests tend to have fuel properties that do not promote fire (van Wilgen et al., 1990), ensuring their survival in the fire-prone landscape. Nonetheless, natural forests in southern Africa cover less than $0.25 \%$ of the landscape (Low and Rebelo, 1996; Midgley et al., 1997).

The lack of a natural source of fast growing timber trees led to the establishment of plantations of alien (introduced) species, beginning in the late 19th century (King, 1943; Le Maitre, 1998a). Plantations of alien trees, primarily pines and eucalypts, now cover 1.52 million ha in South Africa (FOA, 1998). These plantations have brought many benefits. Plantation forestry contributes US\$ 300 million, or $2 \%$, to the GDP and employs over 100,000 people. Downstream industries, based on forestry, produce products worth a further US\$ 1.6 billion, much of which is exported, earning valuable foreign exchange (FOA, 1998).

However, the establishment of these plantations has not been without cost. The negative impacts of afforestation include significant reductions in surface streamflow (Van Lill et al., 1980; Bosch and Hewlett, 1982; Bosch and von Gadow, 1990). Commercial plantations are estimated to have reduced surface runoff by about 1.4 billion $\mathrm{m}^{3}$ peryear or $3.2 \%$, at a national scale (Le Maitre et al., 1997; Scott et al., 1998a). These reductions are important because South Africa has a mean annual rainfall of only $490 \mathrm{~mm}$ and less than $10 \%$ of this becomes surface runoff (Alexander, 1985). Commercial plantation forestry is the only land-use which is restricted because its impacts of afforestation on streamflow (Van der Zel, 1995). Plantations also have substantial impacts on biodiversity and the functioning of natural ecosystems (Armstrong and van Hensbergen, 1996; Allen et al., 1997).

The National Water Act recognises that a portion of the available water needs to be reserved for basic human needs and to sustain natural ecosystems; this places additional constraints on the water available for other uses (Anon., 1970; DWAF, 1986; Walmsley and Davies, 1991; DWAF, 1996). Water is the primary resource that will ultimately limit development in South Africa and efficient management and allocation of water resources is a national imperative (DWAF, 1996).

Unfortunately, many of the plantation species have become major invaders, spreading the negative impacts far beyond the afforested areas. Foremost amongst these are several species of pine (Pinus) and wattle (Acacia). The forestry industry recognises these problems and subscribes to a code of conduct which, among other things, requires that riparian zones and non-afforested areas within the forest estates are kept clear of invading alien plant species (FIEC, 1995). The forest industry has also recognised that the impacts of plantation trees on streamflow are far greater in the riparian zone than outside it (Scott and Lesch, 1995; Scott et al., 1999), and follow a policy of nonafforestation of such zones (FIEC, 1995). The industry also actively supports the government's alien plant control programmes by funding control operations, providing expertise and forming partnerships with Working for Water.

Commercial forestry based on alien trees is a wellestablished feature of the South African landscape and economy, but the invasions that are associated with it are going to have to be managed to minimise conflicts around scarce resources, especially water. As a first step, a clear understanding of the magnitude of the problem needs to be developed, especially in order to establish whether the costs of clearing invaded areas can be justified. Studies to quantify the relative benefits of clearing have been carried out in the Western Cape Province, where mountain catchment areas covered with fynbos shrublands have been invaded by pines and wattles (Le Maitre et al., 1996; van Wilgen et al., 1996, 1997). These areas are subjected to fires at about 15year intervals; the fires trigger the spread of alien trees, initially from adjacent plantation areas, and subsequently from invaded areas in the catchment.

As the problem of invasive alien trees and their impacts was not restricted to the Western Cape Province (Henderson, 1995; Dye and Poulter, 1995), a study was commissioned to estimate the predicted impact on a national level. This study found that about 10.1 million ha, or $6.8 \%$ of South Africa has been invaded to some degree (Versfeld et al., 1998). These 
invasions were estimated to be using almost $6.7 \%$ of the country's runoff, and would cost an estimated US\$ 0.86 billion to clear over 20 years (Le Maitre et al., 2000). While these results were based on very crude estimates of the extent of invasion they were nonetheless convincing enough for the national government to launch an extensive and ambitious control programme aimed at minimising the effects on water resources (van Wilgen et al., 1998).

This paper summarises the findings of management plans that were developed for alien plant control in four representative catchments in South Africa. The aim of these plans was two-fold-firstly to test, at a finer scale, the broad-scale predictions of significant benefits from clearing programmes, and secondly to provide project managers with reasonable estimates of the extent of the task that they faced. In this paper, we compare the composition, extent and impacts of invasive alien trees in the four catchments and provide estimates of the costs and benefits of control operations.

\section{Study sites}

We selected four catchments, representative of a cross-section of the catchments in South Africa in terms of their climate, natural ecosystems, kinds of land-use and the composition of the invading plants (Table 1, Fig. 1).

\subsection{Sonderend River}

This catchment is situated in the rugged Cape Folded Mountains with peaks of over $1600 \mathrm{~m}$ in the Stettynskloof range in the west, Langeberg in the north and Riviersonderend in the south (Gelderblom et al., 1998). The mean annual rainfall varies from $1895 \mathrm{~mm}$ in the upper catchment to $350 \mathrm{~mm}$ in the lower lying areas (Midgley et al., 1994). The dominant vegetation in the lower regions of this catchment was renosterveld (Table 2), a low shrubland which occurs on shalederived soils; most of the renosterveld is now cultivated land and less than 5\% is currently formally conserved (Low and Rebelo, 1996; Gelderblom et al., 1998). The dominant vegetation in the mountain areas is fynbos, a species-rich shrubland with numerous rare and endemic plants.

The runoff from the high-yielding sub-catchments at the western end of the Sonderend supplies the Theewaterskloof dam (capacity 484 million $\mathrm{m}^{3}$ ) which is an important source of water for the greater Cape Town metropolitan area, and for irrigation of deciduous fruit (van Wilgen et al., 1997; Gelderblom et al., 1998).

\subsection{Keurbooms River}

The southern boundary of the Keurbooms catchment is situated on the coast. The mountains to the north are rugged and barely accessible (Gelderblom and Rowlinson, 1999). The main Outeniqua mountain range, elevation $>1200 \mathrm{~m}$, runs east-west and the south-facing slopes are significantly moister than the north-facing slopes. The coastal section includes a broad elevated coastal plateau $(150-250 \mathrm{~m})$ with deeply incised river valleys. The mean annual rainfall ranges from 664-997 $\mathrm{mm}$ in the different sub-catchments and is distributed through the year (Table 1).

The dominant vegetation is mountain fynbos shrublands (Gelderblom and Rowlinson, 1999). There are also extensive areas of the temperate Afromontane forest which is situated mainly in valleys, on southfacing slopes of the coastal mountains and the coastal plateau (Geldenhuys, 1994).

Table 1

Salient features of the four South African catchment areas used in this study ${ }^{\mathrm{a}}$

\begin{tabular}{lllll}
\hline Catchment area & Area $\left(\mathrm{km}^{2}\right)$ & Climate and rainfall season & $\begin{array}{l}\text { Mean annual rainfall in } \\
\text { the catchment }(\mathrm{mm})\end{array}$ & $\begin{array}{l}\text { Mean annual runoff } \\
\left(\mathrm{millions} \text { of } \mathrm{m}^{3}\right)\end{array}$ \\
\hline Sonderend & 2242 & Warm temperate, winter & 634 & 459 \\
Keurbooms & 1380 & Warm temperate, all-year & 811 & 215 \\
Upper Wilge & 6160 & Cool temperate, summer & 723 & 451 \\
Sabie-Sand & 6322 & Temperate to sub-tropical, summer & 891 & 732 \\
\hline
\end{tabular}

${ }^{a}$ See Fig. 1 for the location of the catchments. Catchment areas, rainfall, evaporation and surface runoff data from Midgley et al. (1994). 


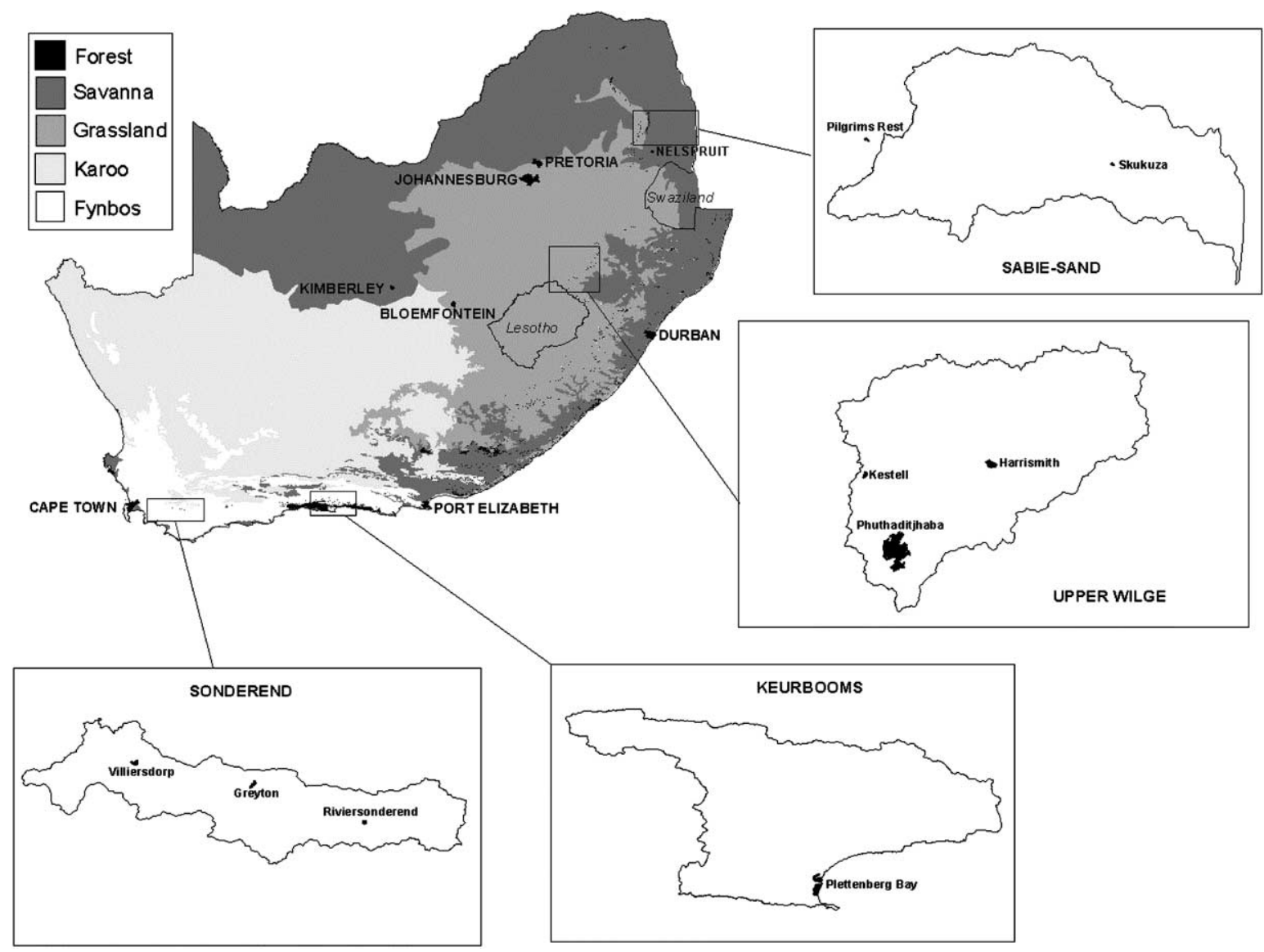

Fig. 1. The distribution of the major biomes in South Africa (Low and Rebelo, 1996) and the location of the four catchments in this study.

The cultivated areas are situated on the coastal plateau in the south-eastern part of the catchment and a substantial area is under plantations (Table 2, Gelderblom and Rowlinson, 1999). The town of Plettenberg Bay near the estuary of the Keurbooms River is a major tourist resort. The agricultural activities include irrigated vegetable and deciduous fruit production and intensive grazing for dairy farming (Gelderblom and Rowlinson, 1999). Agriculture is currently the major water-user and demand for water for agriculture and urban use is expected to increase 2-3 times by 2020 AD (Ninham-Shand, 1996).

\subsection{Upper Wilge River}

The Upper Wilge River catchment is situated on the inland plateau of South Africa. The upper, southern-eastern headwaters are situated along the crest of the Drakensberg Escarpment and in the Maluti Mountains of Lesotho where the peaks reach $3200 \mathrm{~m}$ (Bailey, 1997). The lowest regions in the north-west are $1600-1700 \mathrm{~m}$ with low hills and ridges, gently sloping valleys and meandering rivers. The mean annual rainfall is $723 \mathrm{~mm}$ (Table 1) and varies from $600-1500 \mathrm{~mm}$. There are frequent frosts, and snowfalls in winter in the Maluti Mountains.

The vegetation is mainly a winter-dormant grassland dominated by temperate grasses with woodland or forest limited to river floodplains and sheltered valleys in the mountains (Table 2). There are extensive wetlands which cover about $22 \mathrm{~km}^{2}$. The major landuse practices are extensive grazing, dryland cultivation-mainly for maize production—and irrigated agriculture. There are densely populated townships in 
Table 2

The original vegetation (Low and Rebelo, 1996) and the current land cover (Thompson, 1996, Fairbanks et al., 2000) in the four South African catchment areas used in this study (Bailey, 1997, Gelderblom et al., 1998, Gelderblom and Rowlinson, 1999, Nel et al., 1999)

\begin{tabular}{lll}
\hline Catchment area & Original vegetation (\% of area in parentheses) & Major forms of land cover (\% of area in parentheses) \\
\hline Sonderend & Renosterveld (63) & Natural vegetation (45) \\
& Mountain fynbos (36) & Cultivated lands (53) \\
& Afromontane forest (1) & Forest and plantations (0.3) \\
Keurbooms & Mountain fynbos (75) & Mountain fynbos (65) \\
& Afromontane forest (34) & Indigenous forest (18) \\
& Dune thicket (1) & Cultivated lands (9) \\
& Renosterveld (2) & Forest plantations (7) \\
Upper Wilge & Moist cold highveld grassland (46) & Natural vegetation (69) \\
& Wet cold highveld grassland (43) & Cultivated lands (25) \\
& Moist cool highveld grassland (9) & Degraded lands (3) \\
& Afromontane forest (1) & Natural vegetation (62) \\
Sabie-Sand & Mixed lowveld bushveld (52) & Degraded lands (14) \\
& Sour lowveld bushveld (30) & Forest plantation (14) \\
& Sweet lowveld bushveld (6) & Cultivated lands (5) \\
& Lebombo arid mountain bushveld (6) & \\
\hline
\end{tabular}

Phuthaditjhaba (Fig. 1). Large areas in this vicinity have been over-grazed and degraded because of the over-population of these fragile lands. The catchment is a key water supply area for the major industrial and urban areas of Greater Johannesburg, Pretoria and Vereeniging.

\subsection{Sabie-Sand}

The Sabie-Sand River system has its source in the Drakensberg escarpment, about $2130 \mathrm{~m}$, and flows eastwards to Mozambique (Nel et al., 1999). Mean annual rainfall drops steeply across the escarpment, from $1200-1500 \mathrm{~mm}$ in the headwaters to about 460 $530 \mathrm{~mm}$ in east. The natural vegetation in the upper reaches is winter-dormant, temperate grassland (Table 2) with extensive areas of Afromontane forest in the valleys and the sheltered slopes of the escarpment (Nel et al., 1999). The vegetation of the lower areas comprises closed to open woodlands, savanna and grasslands with gallery forests along the main rivers.

Extensive plantations of pines (mainly Pinus patula) and eucalypts (mainly Eucalyptus saligna) have been established in the upper catchments of both the Sabie and Sand River systems (Table 2, Nel et al., 1999). In the middle reaches, commercial agriculture, mainly irrigated sub-tropical fruit, is the main land-use in formal agricultural areas, while subsistence agriculture is the main land-use in the very densely populated, communally-owned rural areas. About a third of the area falls in the Kruger National Park, a conservation area of international importance.

The water resources in the rivers are heavily utilised (Nel et al., 1999). Plantations in the upper reaches have reduced the natural flow in the Sabie and Sand River systems by about 45 and $31 \%$, respectively (Le Maitre et al., 1997). Irrigation used about $14 \%$ of the natural flow in 1987 while human use and water for livestock accounted for about $1 \%$ of the flow (Nel et al., 1999). There is concern about the ecological impacts of flow reductions on the rivers in the Kruger National Park (Weeks et al., 1996). The flow in the Sabie River almost ceased at the peak of the most recent drought. The demand for water is projected to increase by $115 \%$ by $2010 \mathrm{AD}$ mainly due to increases in human use (800\%) and irrigated agriculture (200\%) (Nel et al., 1999).

\section{Methods}

\subsection{Mapping of invaders}

Different methods were used to map invaded areas in the different catchments. Field mapping was used 
for the Sonderend and Sabie-Sand catchments and for parts of the other two. Mapping followed the guidelines developed by Le Maitre and Versfeld (1994) which provide for a range of density classes from rare (invaders known to be present but canopy cover less than $0.01 \%$ ) to closed (100\% canopy cover). The spatial extent of the invasions was recorded on acetate overlaid on maps from the standard 1:50,000 series for South Africa. Parts of the Upper Wilge River catchment were mapped using high resolution (1$5 \mathrm{~m}$ pixel size) aerial video photography (Bailey, 1997). The information from the video images was transferred to map overlays and verified in the field. Parts of the Keurbooms River catchment were mapped from a helicopter using a Global Positioning System (GPS) (Gelderblom and Rowlinson, 1999). All the spatial data were converted to GIS data layers in Unix ArcInfo format.

Invaded areas were divided into landscape invasions, and riparian and floodplain invasions. This was done to facilitate field mapping and because the invading species and invasion processes differ between the two categories (Le Maitre, 1998b). Landscape invasions are typically extensive and most easily drawn as polygons. Riparian invasions were assessed along segments of the stream or river and the width of the invaded strip was estimated. This width was subsequently used in the GIS to buffer the digitised watercourse and create a polygon. The density class or percentage cover of each species in the invaded area was estimated. The field data were captured and stored as data files in the GIS database. Some of the invasions mapped using videography were not identified to the species level and these were converted to species data using information on the typical proportions of the different species.

\subsection{Additional spatial information}

Information on rainfall and the estimated natural (pre-development) surface runoff was obtained from Midgley et al. (1994). This data set provided estimates of rainfall, surface runoff and evaporation for each sub-catchment comprising the study catchment. The runoff data were supplemented with other information collated during the preparation of the management plans. The catchment boundaries were obtained from coverages made available by Midgley et al. (1994) and
Ninham-Shand (1996). The distribution of the original vegetation types was obtained from GIS data layers prepared by Low and Rebelo (1996) at a scale of about $1: 500,000$. The extent of different categories of current land-use at 1:250,000 was obtained from the national land cover database using Thompson's (1996) classification. The national land cover data were used in all the analyses except for the Keurbooms catchment where the land cover data was supplemented with more detailed information (Ninham-Shand, 1996).

\subsection{Calculation of water-use}

Water-use was estimated using the biomass-based regression model developed by Le Maitre et al. (1996) and adapted and applied by Versfeld et al. (1998). This model estimates the reduction in streamflow $(\mathrm{mm})$ in invaded areas relative to the natural vegetation based on the total above-ground biomass of the invading plants. The model was developed using data from long-term studies which compared the streamflow from natural fynbos shrubland catchments and catchments afforested with pines (Van Wyk, 1987; Scott and Van Wyk, 1992). The relationship is as follows:

stream flow reduction $(\mathrm{mm})$

$$
=\operatorname{biomass}\left(\mathrm{g} / \mathrm{m}^{2}\right) \times 0.238, \quad r^{2}=0.75, \quad n=9
$$

Each invading tree and shrub species was assigned to one of three biomass categories: tall shrub, medium tree and tall tree based on its size when mature and known or estimated water-use. The biomass relationships were as follows (Le Maitre et al., 1996).

Tall shrubs:

biomass $\left(\mathrm{g} / \mathrm{m}^{2}\right)=5240 \times \log _{10}($ age in years $)-415$

Medium trees:

biomass $\left(\mathrm{g} / \mathrm{m}^{2}\right)=9610 \times \log _{10}($ age in years $)-636$

Tall trees:

Tall trees biomass $\left(\mathrm{g} / \mathrm{m}^{2}\right)$

$$
=20000 \times \log _{10}(\text { age in years })-7060
$$

The above relationships require data on, or an estimate of, the age of the plants. Fynbos landscapes burn at intervals between about 10 and 20 years (Richardson et al., 1994). Using the average of 15 years and 
assuming an equal area of each age, this gives a mean age of 7.5 years for landscape invaders in the fynbos areas (Sonderend and Keurbooms). Riparian invaders reach substantially greater ages than landscape invaders, as riparian areas do not burn regularly. In addition, plantation trees in riparian areas use more water than trees of the same age and species away from rivers (Scott et al., 1999). In the fynbos catchments the water-use of species which primarily, or only, invade riparian areas was doubled. In the grassland catchments-Upper Wilge and Sabie-Sand-areas the invasions are primarily riparian, with a mixed age structure. A mean age of 20 years was used for all invasions in riparian or non-fynbos areas.

As water-use estimates were based on a formula derived from plantations with dense stands of trees, we calculated the "equivalent dense" area for invasions in order to estimate streamflow reductions. This is the equivalent extent of the invasion if the canopy cover is adjusted from the actual value to $100 \%$ (Le Maitre et al., 2000). For example, if the mean canopy cover of an area of 100 ha is $25 \%$, then the equivalent dense area is 25 ha. This adjustment of the areas assumes that the relationship between stand density and wateruse is linear.

\subsection{Cost of clearing}

Information on the cost of clearing was obtained from managers of clearing programmes in each of the catchments. In most cases the cost data were obtained in the form of the costs of each operation (e.g. clearing, follow-up) for each of the species and subdivided into three density classes: light $(0-25 \%)$, medium (25-50\%) and dense ( $>50 \%)$ cover (Le Maitre et al., 2000). Species-specific data were preferred because the cost often differs markedly between species: for example, the one requires herbicides to prevent resprouting and the other does not sprout. In some cases, such as the Sabie-Sand catchment, some species occur consistently together as highly variable mixtures. In this case the cost data were specified for the mixture and used in this form. The cost data were expressed as the total cost for the mean percentage cover of each density class, and a linear regression was fitted using the percent canopy cover as the independent variable and cost per hectare as the dependent variable. In some cases a non-linear (exponential) relationship gave a better fit and was used in place of the linear regression.

The data from the mapping of the invaders did not always use the same set of density classes. Therefore all the density classes were converted to the mean percent canopy cover for that class. The percentage cover from the mapped data for each species, or species mixture, was used to calculate the costs per hectare for each year's operations for that species using the regression described above.

The next step in the calculations had to take the following two facts into account (Le Maitre et al., 2000): (a) areas or sites (polygons) invaded by alien species typically have a mixture of species with each occurring at a different density; and (b) the costs per hectare for each species, as given by the managers, included overheads (e.g. transport, administration). If there was more than one species in the invaded area the overhead cost would be distributed between those species; simply adding the species costs would involve double accounting for the overheads. The solution which gave the most reasonable results was to weight each individual species cost using its equivalent dense area- a measure of its relative density. The costs were then summed and divided by the total equivalent dense area to give a weighted mean which included the both different cost for each species and its relative density. The weighted mean cost per hectare was multiplied by the total invaded area to get the total cost for that area and summed for each catchment or management unit.

\subsection{Projection of future expansion and water-use}

Invasions of areas by alien organisms typically show a sigmoid growth curve over time, involving an initial lag period, a period of rapid (exponential) expansion and the final period when expansion slows as the available habitat becomes fully invaded (Drake et al., 1988; Hengeveld, 1989; Le Maitre, 1998b). This curve can be approximated by the logistic growth curve in its discrete or continuous form (Le Maitre, 1998b). We used the discrete form of the logistic curve with an annual time step to estimate the spread of invaders under a scenario of no control.

Given a suitable homogenous habitat, invasions of large areas would probably proceed at essentially the same rate as smaller areas, with the rate being determined largely by factors such as dispersal curves 
and population growth rates and long range colonisations (Skellam, 1951; Mack, 1985; Birks, 1989; Hengeveld, 1989; Clark, 1998). In the real world large areas tend to become invaded more slowly than smaller areas because: (a) larger areas typically contain more variation in habitat suitability or more habitats, not all of which are equally suitable for invasion; and (b) large areas have often been fragmented by human developments which create a mosiac of non-invadable and invadable land-uses. Dispersal rates are reduced by the habitat variability and the fragmentation (Dyer, 1995). The annual rate of increase of the invaded area during the exponential phase ranges from 10 to $30 \%$, with rates being inversely proportional to the area suitable for invasion (Le Maitre, 1998b). Projections of future invasions were done using expansion rates of 10 and $15 \%$ per year.

All areas of land that were cultivated, improved grassland (pasture), plantation, urban, mines, quarries or water bodies were classified as non-invadable or transformed. The remaining land, essentially the remaining natural vegetation, was considered invadable. In the Keurbooms catchment, about $23 \%$ of area is indigenous forest, which is relatively resistant to invasions. The invaded area of forest was assumed to increase at only $1 \%$ per year for this analysis. All of the projected invasions assumed that the relative species composition and the mean density of the invaded areas would remain essentially unchanged as the invaded area increased. In the Sabie-Sand catchment, all the potentially invadable land was mapped as invaded to some extent, or was communal land which was unlikely to be invaded because the plants would be cut down to provide fuel and building materials (Nel et al., 1999). Thus there could be no projected increase in the invaded area and the future condensed area would equal the total invadable area. In this case, the estimates of future impacts were based on rates of increase of 10 and $15 \%$ per year in the density of the invasions.

The estimates of the current volume of water lost from the catchment were based on the equivalent dense (condensed) invaded area. The total volume of water lost was divided by the total condensed area to give a standard reference value in cubic metres per hectare. This value was multiplied by the projected condensed area to calculate the volume of water that could be lost in the future.

\section{Results}

\subsection{Land-use}

The Sonderend catchment has the greatest area under cultivation with 53\% under annual crops and deciduous fruit orchards and the smallest area under plantations $(0.3 \%$ ) (Table 2). Less than $30 \%$ of the renosterveld is left, mostly in small isolated remnants. Most of the vegetation in the Keurbooms catchment is still relatively natural, only $16 \%$ has been transformed. About $10 \%$ of the fynbos and about $50 \%$ of the indigenous forest have been transformed. About 25\% of the grasslands in the Upper Wilge catchment are now cultivated land; the small area of degraded land is situated mainly in the Phuthaditjhaba area. The SabieSand catchment has the largest area under plantations, all situated in the headwater catchments, with cultivated and degraded lands in the middle reaches and the bushveld in the lower reaches inside the Kruger National Park. More than three quarters of the natural grasslands of the upper escarpment have been converted to plantations.

\subsection{Major invading species}

In the Sonderend catchment the pines are the most widespread invaders (total invaded area 92,200 ha), although only a small portion (670 ha) of the catchment is under pine plantations (Tables 3 and 4). The second most important invader is Hakea sericea which is almost exclusively found in the montane fynbos and has invaded about 60,900 ha. Most watercourses and rivers have been invaded to some extent. The upper river valleys have been invaded by Acacia mearnsii. Eucalyptus camaldulensis, together with A. mearnsii has invaded the floodplain of the Sonderend River, particularly the lower reaches, to form closed stands (canopy cover $>75 \%$ ) with trees up to $30 \mathrm{~m}$ tall. In some areas the invaded portion of the floodplain is greater than $200 \mathrm{~m}$ wide.

Invasions in the Keurbooms catchment are similar to those in the Sonderend. The most widespread invader is $H$. sericea which has invaded a total of 43,500 ha $(33 \%$ of the catchment) or the equivalent dense area of 14,192 ha (Table 3) followed by the pines with an equivalent dense area of 7654 ha. Both hakeas and pines are largely confined to fynbos areas 
Table 3

Important invasive tree and shrub species and extent of invasion in four South African catchment areas ${ }^{\mathrm{a}}$

\begin{tabular}{|c|c|c|c|c|c|}
\hline \multirow[t]{2}{*}{ Species } & \multirow{2}{*}{$\begin{array}{l}\text { Growth } \\
\text { form }\end{array}$} & \multicolumn{4}{|l|}{ Catchment } \\
\hline & & Sonderend & Keurbooms & Upper Wilge & Sabie-Sand \\
\hline Cluster pine (Pinus pinaster) & Tree & $8772(41.0)$ & $5033(23.1)$ & - & - \\
\hline Monterey pine ( $P$. radiata) & Tree & $46(0.3)$ & $2621(10.6)$ & - & - \\
\hline Silky hakea (Hakea sericea) & Tree & $1783(27.4)$ & $14192(32.6)$ & - & - \\
\hline Sugar Gum (Eucalyptus cladocalyx) & Tree & $1507(8.8)$ & - & - & - \\
\hline Black wattle (Acacia mearnsii) & Tree & $3662(12.7)$ & $2928(36.3)$ & $\begin{array}{l}\text { Included under } \\
\text { Acacia } \text { species }\end{array}$ & $948(3.3)$ \\
\hline Port Jackson willow (A. saligna) & Tree & $513(8.2)$ & $3(0.5)$ & - & - \\
\hline Rooikrantz (A. cyclops) & Tree & $88(6.16)$ & $162(2.0)$ & - & - \\
\hline Long-leaf acacia (A. longifolia) & Tree & $627(5.2)$ & - & - & - \\
\hline Eucalypt species & Tree & - & $52(1.6)$ & $2306(0.8)$ & $3668(7.3)$ \\
\hline Acacia species & Tree & - & $710(2.3)$ & $2211(0.6)$ & $645(2.2)$ \\
\hline Pine species & Tree & - & $705(4.0)$ & $424(0.3)$ & $2718(6.4)$ \\
\hline Poplar (Populus canescens) & Tree & $146(0.9)$ & - & $292(0.1)$ & $256(1.1)$ \\
\hline Willow (Salix babylonica) & Tree & $64(1.4)$ & - & $707(0.4)$ & - \\
\hline Bugweed (Solanum mauritianum) & Shrub & - & - & - & $5993(6.2)$ \\
\hline Lantana (Lantana camara) & Scrambler & - & - & - & $5867(10.5)$ \\
\hline Guava (Psidium guajava) & Tree & - & - & - & $2659(9.1)$ \\
\hline Brambles (Rubus cuneifolius) & Scrambler & $44(0.9)$ & - & - & $2119(3.5)$ \\
\hline Mauritius thorn (Caesalpinia decapetala) & Scrambler & - & - & - & $1979(8.0)$ \\
\hline Prickly pear (Opuntia stricta) & Succulent & $5(0.8)$ & - & - & 1746 \\
\hline Other & Various & 795 & 335 & 411 & 3018 \\
\hline
\end{tabular}

${ }^{a}$ Data are in hectares of equivalent dense infestation (see text); the total invaded area as a percentage of the catchment area is given in parentheses. Acacia species: mixture of A. mearnsii, A. dealbata in the Upper Wilge and A. melanoxylon in Sabie-Sand. Eucalypt species: mainly E. grandis in the Sabie-Sand. Pine species: mainly P. patula, P. elliottii except in the Keurbooms.

in the inland mountains. A. mearnsii is found along all the major rivers in the catchment where it has invaded the floodplain, in places more than $100 \mathrm{~m}$ across, and is spreading up the tributaries. A. melanoxylon (blackwood) is a significant invader of indigenous forests and riparian areas although its density is still low $(2.5 \%$ cover $)$.

The Upper Wilge catchment is the least invaded of the four included in this analysis (Table 4). The most important invaders are eucalypts and pines (Table 3 )

Table 4

Current extent of transformed land, plantations and current and projected extent of alien plant invaded areas in four South African catchments ${ }^{\mathrm{a}}$

\begin{tabular}{|c|c|c|c|c|c|}
\hline \multirow[t]{2}{*}{ Catchment } & \multirow{2}{*}{$\begin{array}{l}\text { Area of transformed } \\
\text { land excluding } \\
\text { commercial plantations } \\
\text { (ha) }(\% \text { of catchment })\end{array}$} & \multirow{2}{*}{$\begin{array}{l}\text { Area under } \\
\text { plantations (ha) } \\
\text { (\% of catchment) }\end{array}$} & \multicolumn{2}{|c|}{$\begin{array}{l}\text { Total invaded area [equivalent area } \\
\text { of dense invasion] (ha) }\end{array}$} & \multirow{2}{*}{$\begin{array}{l}\text { Range of time period } \\
\text { (years) needed to reach } \\
95 \% \text { of potential invasion } \\
\text { at expansion rates of } \\
10 \text { and } 15 \% \text { per year }\end{array}$} \\
\hline & & & Current & Potential & \\
\hline Sonderend & 108615 (48.6) & $746(0.3)$ & 97725 [17941] & 114849 [22851] & $11-16$ \\
\hline Keurbooms & $9608(6.9)$ & $6138(4.4)$ & 74092 [26683] & 106475 [41079] & $21-31$ \\
\hline Upper Wilge & 196538 (31.9) & $1456(0.2)$ & $11771[6347]$ & 431118 [232462] & $50-76$ \\
\hline Sabie-Sand & $207367(32.8)$ & $102833(16.3)$ & 143305 [31 619] & 143305 [143305] & $26-30$ \\
\hline
\end{tabular}

${ }^{a}$ Transformed land includes all areas where the natural vegetation has been transformed to cultivated land, urban land (including industrial), waterbodies, mines and quarries. In the Sabie-Sand transformed land includes the communal land (182,000 ha) which has generally been disturbed or degraded and includes many dense settlements. All the invadable land in the Sabie-Sand catchment was already invaded to some extent so the projections are for the time required to reach a mean density of $100 \%$ canopy cover. This is why the projected equivalent dense area is the same as the invadable area. 
which have spread from woodlots, shelter belts and other amenity plantings. Acacia species, notably $A$. mearnsii and $A$. dealbata, are widespread along the rivers together with willow and poplar species.

Pines are the major invaders of the grasslands in the upper catchments of the Sabie-Sand Rivers (Table 3), but in the plantation areas and grasslands the major invaders are Solanum mauritianum, Lantana camara and Rubus species, often occurring in mixtures. The plantation margins and the unplanted riparian strips are particularly susceptible to invasion. In the lower regions of the plantations Psidium guajava becomes an important member of these mixtures. Caesalpinia decapetala is a major invader in the middle and lower reaches of the river systems. Invasions by Eucalyptus are largely confined to the plantation areas at present but they could also spread downstream. In the lower parts of the catchment, where the rainfall is less than about $800 \mathrm{~mm}$, invasions are largely confined to the riverbanks and watercourses. The exception to the riparian rule is Opuntia stricta. This species occurs in the Kruger National Park where it has invaded 69,800 ha of the bushveld savanna and woodland and has a mean canopy cover of $2.5 \%$.

\subsection{Current and projected invasions}

Close to half the area of the Sonderend catchment has been transformed and most of the remaining natural vegetation has been invaded (Table 4). About three quarters of the invaded area is in fynbos and the rest in renosterveld. The mean percentage cover in the invaded areas is $18 \%$ with riparian invasions being dense to closed compared with sparse invasion on the mountain slopes. The invaded area can potentially increase by at least $18 \%$ and this could happen in a period of 11-16 years depending on the annual rate of expansion of the invaded areas.

In contrast, close to $90 \%$ of the Keurbooms catchment is still under natural vegetation although about $65 \%$ of the fynbos has been invaded to some degree (Table 4). The indigenous forest is the least affected by invasions which cover about $25 \%$ and have a mean canopy cover of $18 \%$. Most of the invaded area is concentrated in the medium $(25-50 \%$ cover $)$ to dense $(>50 \%$ cover $)$ riverine invasions. The mean canopy cover in the invaded areas is high at $37 \%$ and approximately 9500 ha has dense or closed invasions.
The total invaded area could increase by about $44 \%$ during the next 20-30 years with virtually all of the increase being in the fynbos catchments which have the highest water yields.

About $30 \%$ of the natural grasslands of the Upper Wilge catchment has been converted to cultivated lands, mostly for maize production (Table 4). The area under plantations is very limited and unlikely to increase because the cold climate does not favour commercial forestry. Less than $2 \%$ of the catchment has been invaded at present but very large areas are still natural grassland and potentially could be invaded over the next 50-76 years. The projected area and the time period for the invasions are highly dependent on the extent to which grassland management practices (such as fire exclusion and overgrazing) prevent or limit invasions of non-riparian areas. Riparian areas are naturally prone to invasions and could be invaded far faster than the landscapes. Riparian invasions currently cover $4-15 \%$ of the river length (mean $7 \%$ ) but, given an increase in extent of $20 \%$ per year, which is likely, the entire river system would be invaded in about 35 years.

More than half of the Sabie-Sand catchment has either been transformed or put under plantations (Table 4). About $23 \%$ of the catchment has already been invaded but, as this represents the full extent of habitat suitable for invasion, only the density of the invasions is expected to increase. Without control operations it is likely that all the currently invaded areas will increase in density from 22 to $100 \%$ canopy cover in the next 20-30 years. This estimate may well be conservative given the known rapid growth rates and effective dispersal of aggressive invaders such as L. camara and C. decapetala.

\subsection{Current and projected impacts on water resources and costs of clearing}

Invading alien plants in the Sonderend catchment are estimated to have reduced river flows by $7 \%$ and have the potential, if uncontrolled, to reduce the flow by more than $40 \%$ (Table 5). Dense stands of invaders reduce flows by the equivalent of $1856 \mathrm{~m}^{3} /$ ha per year, essentially the same as the plantations at $1876 \mathrm{~m}^{3}$ per year. Pines account for more than half the volume of water, A. mearnsii a further $20 \%$, eucalypts $12 \%$ and Hakea species $6 \%$. At the current levels of infestation 
Table 5

Estimated reduction in water yields and costs of clearing at current and expected future invasions of alien plants, mainly woody shrubs and trees, in four South African catchment areas ${ }^{\mathrm{a}}$

\begin{tabular}{|c|c|c|c|c|c|}
\hline \multirow[t]{2}{*}{ Catchment area } & \multicolumn{3}{|c|}{ Water-use (millions of $\mathrm{m}^{3}$ and $\%$ of total runoff) } & \multicolumn{2}{|c|}{ Cost to clear (US\$ millions) } \\
\hline & $\begin{array}{l}\text { Commercial } \\
\text { plantations }\end{array}$ & $\begin{array}{l}\text { Invasive trees } \\
\text { (current) }\end{array}$ & $\begin{array}{l}\text { Invasive trees } \\
\text { (potential) }\end{array}$ & $\begin{array}{l}\text { At current levels } \\
\text { of infestation }\end{array}$ & $\begin{array}{l}\text { At future levels } \\
\text { of infestation }\end{array}$ \\
\hline Sonderend & $1.4(0.3)$ & $33.3(7.2)$ & $190.8(41.5)$ & 13.2 & 86.5 \\
\hline Keurbooms & $11.5(5.7)$ & $47.4(22.1)$ & $204.2(95.5)$ & 9.9 & 20.5 \\
\hline Upper Wilge & $0.5(0.1)$ & $26.9(6.0)$ & $1127.4(251)$ & 4.1 & 278.0 \\
\hline Sabie-Sand & $138.2(18.9)$ & $69.3(9.4)$ & $162.9(22.3)$ & 6.6 & 11.1 \\
\hline
\end{tabular}

${ }^{a}$ The flow reductions due to plantations are calculated from data in Le Maitre et al. (1997). In the Upper Wilge catchment the flow reductions at maximum potential invasion exceed $100 \%$. If reductions are restricted to $100 \%$ of the flow, the corresponding invaded area would be 184,136 ha which would be reached after 35 years; the costs of clearing would then be US\$102.6 million.

the costs of clearing the invaded area would be US\$ 13 million or US $\$ 738 /$ ha for the equivalent dense stands. Long-term maintenance after the initial programme is completed would cost about US\$ 0.4 million per year. The cost of the control programme would increase more than 6.5-fold over the next 11-16 years if no action was taken. The current plan for the catchment is that the clearing programme will spend about US\$ 8.4 million over the next 5 years on clearing and initial follow-up on most of the invaded area, The highest priority will be given to clearing the invaded riparian areas, starting with the most upstream invaders.

Invading alien plants have reduced surface runoff in the Keurbooms catchment by about $20 \%$, four times as much as the plantations. Invading pines account for $46 \%$ of the total volume of water, Hakea species $32 \%$ and Acacia species, notably A. mearnsii, for $21 \%$. The flow reductions per unit area are similar to those for the Sonderend at about $1874 \mathrm{~m}^{3}$ per year for plantations and $1776 \mathrm{~m}^{3}$ per year for invading plants. In the absence of clearing, the estimated flow reduction would increase about five-fold over the next 20-30 years, resulting in the loss of virtually all the surface water in the Keurbooms river system. The total cost of controlling the invaders is currently about US\$ 9.9 million in total, or US\$ 372 per equivalent dense ha, and these total costs can potentially double if no action is taken. The costs per unit area are much lower than those for the Sonderend mainly because Hakea was excluded from the clearing because effective biocontrol agents are already present. About $61 \%$ of the total budget would be spent on clearing pines and $36 \%$ on clearing Acacia species.
The impact of plantations on surface runoff in the Upper Wilge catchment is negligible but invaders are estimated to have reduced runoff by $27 \%$ or $4219 \mathrm{~m}^{3}$ per year (Table 5). Eucalypts account for $39 \%$ of the water by volume, Acacia species $37 \%$, Salix species and pines each $7 \%$ and Populus species 4\%. If the invaders were allowed to spread unchecked into the grasslands they could use all the surface runoff in the catchment in about 35 years time. As pointed out above, the rivers could be invaded even more rapidly. The total cost of the control programme, currently US\$ 4.2 million (US\$ 645 per condensed ha), would increase more than 25 -fold over those 35 years. Control of Acacia species comprises about $40 \%$ of the total cost, eucalypts $26 \%$, Salix species $11 \%$, pines $7 \%$ and poplars $6 \%$.

In the Sabie-Sand catchment the current total flow reduction due to invasive aliens (estimated at 69 million $\mathrm{m}^{3}$ per year) is about half that of the plantations but could exceed that of plantations in the next 25-30 years (Table 5). On a unit area basis the invaders are estimated reduce the flow by about $2192 \mathrm{~m}^{3}$ per year compared with plantations at $1344 \mathrm{~m}^{3}$ per year. Eucalypts account for $24 \%$ of the total flow reduction, followed by pines (18\%), Solanum (14\%), Lantana (13\%) and Acacia species (10\%). The control costs are currently about US\$ 6.6 million (US\$ 210 per condensed ha) and would increase 1.7 times if no control programmes were implemented. The costs increase relatively little despite the projected increase in density largely because the costs for dense stands were little higher than for medium density stands. Control operations for invasions comprising mixtures 
of Lantana, Solanum, Caesalpinia and Rubus account for about $76 \%$ of the total costs for the catchment, with $9 \%$ for pines, $8 \%$ for eucalypts and the remainder for acacias. Clearly the benefits in terms of water yield are higher per unit area for clearing eucalypts and pines than for other species.

\section{Discussion}

\subsection{Invasion patterns}

The invaded state of the four catchments reported on here is typical of those in the higher rainfall areas of South Africa. These catchments have a relatively high agricultural potential and the natural vegetation on the arable areas has been transformed or modified by use for extensive grazing. The extensive invasions in the Sonderend and Keurbooms catchments are typical of those of mountain catchments in the Western Cape (Le Maitre et al., 2000). Fynbos is known to be peculiarly susceptible to invasions by woody shrubs and trees, notably the pines and Hakea species (Macdonald, 1984; Richardson and Cowling, 1992; Richardson et al., 1992). A wide range of invading species like those found in the Sabie-Sand catchment is typical of the high rainfall, warm temperate and sub-tropical areas of South Africa (Macdonald, 1983; Henderson and Wells, 1986; Henderson, 1989).

Riparian zones appear to be particularly prone to invasion, probably because they are often disturbed by floods, include extensive ecotones which are the preferred habitat of many invaders, and water is freely available for growth and seed dispersal (Henderson and Musil, 1984; Thebaud and Debussche, 1991; Pysek and Prach, 1993; Le Maitre, 1998b). Major invaders of the riparian zones in all these catchments are A. mearnsii or A. dealbata. The extensive invasions by Eucalyptus species in the lower Sonderend River are unusual as this genus is rarely invasive (Richardson, 1998). Similar invasions are found in the lower Berg River in the Western Cape (Versfeld et al., 1998) but the factors facilitating these invasions are unknown.

The low degree of invasion of catchments such as the Upper Wilge should not be a cause for complacency. The potential for spread is significant and the catchment is still in the early stage of invasion when expansion rates can be expected to be low (Le Maitre, 1998b). Modelling of the expansion suggests the exponential phase of the expansion will be reached in about 15 years time (Le Maitre unpublished data), and probably sooner in the rivers. The annual investment needed even to maintain the status quo at that stage will be much greater than it would be now. The invasions in the Sonderend and Keurbooms catchments are in the exponential phase although effective biocontrol of $H$. sericea in the Keurbooms catchment could limit expansion rates in that catchment (Gelderblom and Rowlinson, 1999).

\subsection{Flow reductions}

The model used to estimate the impacts of invading plants on streamflow is a very simple one and there is concern about the reliability of its estimates (Le Maitre et al., 2000). The predicted reductions, mean $1900 \mathrm{~m}^{3} /$ ha per year, were more than twice those estimated for plantation areas in South Africa of $930 \mathrm{~m}^{3} / \mathrm{ha}$ per year (Le Maitre et al., 1997; Scott et al., 1998a). These differences could be explained by the lower mean age of plantations and because the afforested areas generally exclude riparian zones (Le Maitre et al., 2000). Although the biomass model is based on data that gave a reasonable fit (Le Maitre et al., 1996), it is derived from winter rainfall catchments (Le Maitre et al., 2000). Nevertheless, its predictions for streamflow reductions are in line with those reported for summer rainfall catchments afforested with pines and eucalypts in South Africa (Bosch and von Gadow, 1990; Dyer, 1995; Scott et al., 1999) and elsewhere (Bosch and Hewlett, 1982). A number of short-term studies have also shown that clearing of invaders results in enhanced streamflow, supporting the basic principle that invading trees use more water than the indigenous vegetation (Dye and Poulter, 1995; Olbrich and Poulter, 1997; Prinsloo and Scott, 1999).

Two independent studies have been done in the KwaZulu-Natal Province (Umgeni Water, 1998a,b). The impacts on river flows were estimated using a detailed soil moisture budgeting model (Schulze et al., 1995). Current reductions were estimated at 11 and 19 million $\mathrm{m}^{3}$ per year, respectively, and would increase to 21 and 30 million $\mathrm{m}^{3}$ per year, respectively, in 20 years time if no control operations were implemented. 
On a unit area basis the initial reductions are equivalent to 5602 and $4354 \mathrm{~m}^{3} /$ ha per year, respectively, greater than those for any of the catchments in our analysis. These findings provide further support for our estimates.

\subsection{Reliability of the estimates}

The impacts described are substantial and it is important to give an indication of their reliability. This is not a simple issue as there are several sources of uncertainty (see also Le Maitre et al., 2000). The regression equations used to estimate biomass from age and flow reduction from biomass all have $95 \%$ confidence limits of $\pm 20-30 \%$. The assignment of species to biomass categories, based on expert opinion in the absence of water-use data, also introduces an unknown degree of error in the water-use estimates. The mapping of the invaded areas, information on the species composition and density, and the estimated age of the invaders are potentially further sources of error; their magnitude and whether any of them has been either under- or over-estimated is simply not known at present. These estimates are the best possible under the circumstances and, given that the impacts will increase because the invasions will become worse, should support the argument that pre-emptive action is wiser than waiting for more accurate data.

\subsection{Costs}

The costs of these control programmes appear to be prohibitive but this depends on how the costs are interpreted. If, for example, a control programme would require 15 years to complete and would save $50 \%$ of the total volume of water that would have been lost through invading plants during that time, the costs would be as follows: Sonderend $7 \phi$ per $\mathrm{m}^{3}$, Keurbooms $3 \phi$ per $\mathrm{m}^{3}$, Upper Wilge $2 \phi$ per $\mathrm{m}^{3}$ and SabieSand $1 \phi$ per $\mathrm{m}^{3}$. As the additional water would be available in perpetuity, the long-term benefits would be substantially greater. In the Sonderend catchment, the current water allocation to various user groups is about 266 million $\mathrm{m}^{3}$ per year and the charges for water range from $0.01 \phi-4.44 \phi$ per $\mathrm{m}^{3}$ (Gelderblom et al., 1998). The cost of the control programme could be financed with an additional levy of about $1 \phi$ per $^{3}$ and the income from a levy of $0.15 \phi$ per $\mathrm{m}^{3}$ would cover long-term maintenance. Alternatively the income from the water released by clearing, at the current tariffs, would more than cover the costs of maintenance. The opportunity costs of the water currently used by alien invaders, if charged at the agricultural sector tariff of $2 \phi$ per $\mathrm{m}^{3}$, would amount to US\$ 0.55 million per year. A similar analysis for the Keurbooms River catchment gives an additional charge of $1 \phi$ per $\mathrm{m}^{3}$ for the control programme and $0.1 \notin$ per $\mathrm{m}^{3}$ for long-term maintenance (Gelderblom and Rowlinson, 1999). In this case the opportunity costs of the water used by alien plants, at $2 \varnothing$ per $^{3}$, are US\$ 1.09 million per year.

Our analyses have focussed on the direct costs of control and the opportunity cost of the additional water transpired by invading plants at the tariffs charged for water resources. These are only a small proportion of the total economic benefits that can be obtained from water (e.g. income from crops, industry and the meeting of basic human needs and health requirements) (Gleick, 1998; Schreiner, 1999). A comparison of the benefits accruing from water used for irrigated crops and commercial tree production in the Crocodile River catchment, adjacent to the SabieSand catchment, found that income from off-farm sales ranged from US\$ $0.10-$ US $\$ 2.92$ per $\mathrm{m}^{3}$ with a mean of US\$ 0.77 per $\mathrm{m}^{3}$ (Olbrich and Hassan, 1999). Based on these values, the opportunity cost of the flow reductions due to alien plant invasions in the Sabie-Sand River system is about US\$ 53 million per year.

The introduction of biocontrol agents to reduce seed production by the major invaders which are still used commercially (e.g. pines, A. mearnsii) will reduce conflicts of interest and also could reduce control costs significantly in the future (van Wilgen et al., 2000). Ongoing maintenance to eliminate new invasions will also reduce expenditure in the long-term.

\subsection{Other benefits}

Clearing infestations of invading alien plants will have many other benefits, besides enhancing water supplies. These include preventing the loss of biodiversity, reducing fire hazard, stabilizing catchment areas and preventing erosion, and deriving social benefits from job creation in labour-intensive clearing programmes. 
Invasive organisms are considered to be one of the most important threats to biodiversity worldwide (Vitousek et al., 1997; Bright, 1998) and the situation in South Africa is no different. The Cape fynbos flora is renowned for its biodiversity with about 8754 plant species, $68.2 \%$ of which are endemic. A large number or rare and endangered plants species are known to occur in the fynbos in the Sonderend and Keurbooms catchments and the indigenous forest in the latter provides a habitat for endemic bird and mammal species (Gelderblom et al., 1999; Gelderblom and Rowlinson, 1999). The Maluti Mountains in the Upper Wilge catchment are part of the Eastern Mountain centre of plant biodiversity which includes at least 30 endemic plant species (Davis and Heywood, 1994; Cowling and Hilton-Taylor, 1994). The Drakensberg escarpment in the Sabie-Sand catchment is part of the Wolkberg centre of biodiversity (Cowling and HiltonTaylor, 1994), with about 163 red data book plant species (Matthews et al., 1993; Nel et al., 1999) as well as red data bird species (Allen et al., 1997), reptiles, amphibians and mammals. The Sabie-Sand River system also supports a rich aquatic fauna, including endemic fishes (Russel and Rodgers, 1989; O'Keeffe et al., 1996; Weeks et al., 1996).

Invasions by alien trees and shrubs increase the fuel loads and thus the intensity and severity of the resulting fires (van Wilgen and Richardson, 1985). The increased intensity of fires in invaded areas makes them more difficult to control (Chandler et al., 1983). The increased severity of the fires also results in greater damage to soils through heating and combustion of the organic matter which, in turn, can result in water repellency and severe soil erosion (DeBano and Rice, 1973; Giovannini and Lucchesi, 1983; Scott and Van Wyk, 1990, 1992; Scott, 1993; Scott et al., 1998b). The risk of severe flooding is also increased by the increased surface runoff and higher peak flood water volumes (Scott et al., 1991). The effects of the changes in soil wettability and water infiltration can persist for many years (Scott and Van Wyk, 1992). The risks of damage to property and the loss of human lives or severe injuries are also greatly increased. The severe fires also kill seeds in the soil and sprouting plant species (Richardson and van Wilgen, 1986; Holmes et al., 2000).

One of the major motivations for the alien plant control programme is its success in achieving its social objectives through job creation (van Wilgen et al., 1998; Working for Water, 1999). This is why the main source of income for the programme is government and donor poverty-relief funds. The programme has been used to provide employment to thousands of previously unemployed South Africans. It has focussed on issues such as gender and racial equity, opportunities for the youth, the disabled and single parents, training and empowerment, and environmental awareness. This focus has meant that the benefits of employment are carried beyond mere job creation towards the reforming of society. Such an approach can have benefits that are difficult to quantify in monetary terms.

The results of these studies support the belief that clearing programmes are a wise and cost-effective method of protecting vital water resources in South Africa. It should be noted, however, that alien tree species have brought many benefits beside those from commercial plantations. Alien trees play important roles in providing fuel and other products to rural communities, in land restoration, and in the developing agro-forestry field. The key is to identify strategies that will allow for minimisation of the costs of controlling invading plants while maximising the benefits. Key elements in this approach will include the establishment of early warning systems and other precautionary measures to either exclude highly invasive species or to eliminate unwanted invasions at an early stage.

\section{Acknowledgements}

This study and the development of the management plans for the different catchments was funded by the South African Department of Water Affairs and Forestry, through it's Working for Water Programme.

\section{References}

Alexander, W.J.R., 1985. Hydrology of low latitude southern hemisphere land masses. Hydrobiologia 125, 75-83.

Anon., 1970. Commission of Enquiry into Water Matters. Government Printer, Cape Town.

Allen, D.G., Harrison, J.A., Navarro, R.A., van Wilgen, B.W., Thompson, M.W., 1997. The impact of commercial afforestation on bird populations in Mpumalanga province, South 
Africa-insights from bird atlas data. Biol. Conserv. 79, 173185.

Armstrong, A.J., van Hensbergen, H.J., 1996. Impacts of afforestation with pines on assemblages of native biota in South Africa. S. Afr. For. J. 175, 35-42.

Bailey, C., 1997. Management plan for the Upper Wilge River catchment. Report No. ENV/P/C 97227, Division of Water, Environment and Forestry Technology, CSIR, Pretoria.

Birks, H.J.B., 1989. Holocene isochrone maps and patterns of treespreading in the British Isles. J. Biogeogr. 16, 503-540.

Bosch, J.M., Hewlett, J.D., 1982. A review of catchment experiments to determine the effect of vegetation changes on water yield and evaporations. J. Hydrol. 55, 3-23.

Bosch, J.M., von Gadow, K., 1990. Regulating afforestation for water conservation in South Africa. S. Afr. For. J. 153, 41-54.

Bright, C., 1998. Life Out of Bounds: Bioinvasion in a Borderless World. Worldwatch Institute, WW Norton \& Company, New York.

Chandler, C., Cheney, P., Thomas, P., Trabaud, L., Williams, D., 1983. Fire in Forestry. Vol. 1. Forest Fire Behaviour and Effects. Wiley, New York.

Clark, J.S., 1998. Why trees migrate so fast: confronting theory with dispersal biology and the paleorecord. Am. Naturalist 152, 204-224.

Cowling, R.M., Hilton-Taylor, C., 1994. Patterns of plant diversity and endemism in southern Africa: an overview. In: Huntley, B.J. (Ed.), Botanical Diversity in Southern Africa. Strelitzia 1, pp. $31-52$.

Davis, S.D., Heywood, V.H. (Eds.), 1994. Centres of Plant Diversity: A Guide and Strategy for their Conservation. Monographs in Systematic Botany, Missouri Botanic Garden 25, pp. 1-94.

DeBano, L.F., Rice, R.M., 1973. Water repellent soils: their implications in forestry. J. For. 71, 220-223.

Drake, J.A., Mooney, H.A., di Castri, F., Groves, R.H., Kruger, F.J., Rejmanek, M., Williamson, M. (Eds.), 1988. Biological Invasions. A Global Perspective. SCOPE 37. Wiley, Chichester, UK.

DWAF, 1986. Management of the water resources of the Republic of South Africa. Department of Water Affairs, Pretoria.

DWAF 1996. Sustainable forest development in South Africa-The policy of the government of national unity. White Paper. Department of Water Affairs and Forestry, Pretoria.

Dye, P.J., Poulter, T., 1995. A field demonstration of the effects on streamflow of clearing invasive pines and wattle trees from a riparian zone. S. Afr. For. J. 173, 27-30.

Dyer, J.M., 1995. Assessment of climatic warming using a model of forest species migration. Ecol. Modelling 79, 199-219.

FIEC, 1995. Guidelines for environmental conservation management in commercial forests in South Africa. Forestry Industry Environmental Committee, Forest Owners Association, Johannesburg.

FOA, 1998. Abstract of South African forestry facts for the year 1996/1997. Forest Owners Association, Johannesburg.

Geldenhuys, C.J., 1994. Bergwind fires and the location pattern of forest patches in the southern Cape landscape, South Africa. J. Biogeogr. 21, 49-62.
Gelderblom, C., Rowlinson, L., 1999. Management plan for alien vegetation in the Keurbooms catchment. Report No. ENV/S-C 98057A \& B, Division of Water, Environment and Forestry Technology, CSIR, Stellenbosch.

Gelderblom, C., van Wyk, E., van Wilgen, B., 1998. Management plan for alien vegetation in the Riviersonderend catchment. Report No. ENV/S-C 980173A \& B, Division of Water, Environment and Forestry Technology, CSIR, Stellenbosch.

Giovannini, G., Lucchesi, S., 1983. Effect of fire on hydrophobic and cementing substances of soil aggregates. Soil Sci. 136, 231-236.

Gleick, P.H., 1998. The human right to water. Water Policy 1, 487503.

Henderson, L., 1989. Invasive alien woody plants of Natal and the north-eastern Orange Free State. Bothalia 19, 237-261.

Henderson, L., 1995. Plant invaders of Southern Africa. Plant Protection Research Institute Handbook No. 5, Plant Protection Research Institute, Agricultural Research Council, Pretoria.

Henderson, L., Musil, K.J., 1984. Exotic woody plant invaders of the Transvaal. Bothalia 15, 297-313.

Henderson, L., Wells, M.J., 1986. Alien plant invasions in the grassland and savanna biomes. In: Macdonald, I.A.W., Kruger, F.J., Ferrar, A.A. (Eds.), The Ecology and Management of Biological Invasions in Southern Africa. Oxford University Press, Cape Town, pp. 109-117.

Hengeveld, R., 1989. Dynamics of Biological Invasions. Chapman \& Hall, London.

Holdridge, L.R., Grenke, W.C., Hatheway, W.H., Liang, T., Zosi, J.A., 1971. Forest Environments in Tropical Life Zones. Pergamon Press, Oxford.

Holmes, P.M., Richardson, D.M., van Wilgen, B.W., Gelderblom, C., 2000. The recovery of South African fynbos vegetation following alien woody plant clearing and fire: implications for restoration. Austral Ecol. 25, 631-657.

King, N.L., 1943. Historical sketch of the development of forestry in South Africa. J. S. Afr. For. Assoc. 1, 4-16.

Le Maitre, D.C., 1998a. Pines in cultivation: a global view. In: Richardson, D.M. (Ed.), Ecology and Biogeography of Pinus. Cambridge University Press, Cambridge, pp. 407-431.

Le Maitre, D.C., 1998b. An analysis of invasion processes and risks and a strategy for modelling invasions by alien plant species at a national and regional scale. Appendix 7. In: Versfeld, D.B., Le Maitre, D.C., Chapman, R.A. (Eds.), Alien Invading Plants and Water Resources in South Africa: A Preliminary Assessment. Report TT99/98, Water Research Commission, Pretoria, 31 pp.

Le Maitre, D.C., Versfeld, D.B., 1994. Field Manual for mapping populations of invasive plants for use with the Catchment Management System. Report FOR-DEA, Department of Environment Affairs, Pretoria.

Le Maitre, D.C., Scott, D.F., Fairbanks, D.H.K., 1997. The impacts of timber plantations on runoff in South Africa: a handy reference manual. Report ENV/S-C 96068, Department of Water Affairs and Forestry, Pretoria.

Le Maitre, D.C., van Wilgen, B.W., Chapman, R.A., McKelly, D.H., 1996. Invasive plants and water resources in the western Cape Province, South Africa: modelling the consequences of a lack of management. J. Appl. Ecol. 33, 161-172. 
Le Maitre, D.C., Versfeld, D.B., Chapman, R.A., 2000. The impact of invading alien plants on surface water resources in South Africa: a preliminary assessment. Water SA 26, 397408.

Low, A.B., Rebelo, A.G. (Eds.), 1996. Vegetation of South Africa Lesotho and Swaziland. Department of Environment Affairs and Tourism, Pretoria.

Macdonald, I.A.W., 1983. Alien trees, shrubs and creepers invading indigenous vegetation in the Hluhluwe-Umfolozi Game Reserve complex in Natal. Bothalia 14, 949-959.

Macdonald, I.A.W., 1984. Is the fynbos biome especially susceptible to invasion by alien plants? A re-analysis of the available data. S. Afr. J. Sci. 80, 369-377.

Mack, R.N., 1985. Invading plants: their potential contribution to population biology. In: White, J. (Ed.), Studies on Plant Demography: a Festschrift for John L Harper. Academic Press, London, pp. 127-142.

Manders, P.T., 1990. Fire and other variables as determinants of forest/fynbos boundaries in the Cape Province. J. Veg. Sci. 1, 483-490.

Manders, P.T., Richardson, D.M., 1992. Colonisation of Cape fynbos communities by forest species. For. Ecol. Manage. 48, 277-293.

Matthews, W.S., van Wyk, A.E., Bredenkamp, G.J., 1993. Endemic flora of the north-eastern Transvaal escarpment, South Africa. Biol. Conserv. 63, 83-94.

Midgley, D.C., Pitman, W.V., Middleton, B.J., 1994. The surface water resources of South Africa 1990 (First Edition). Vols. 1-6. Report Numbers 298/1.1/94 to 298/6.1/94 (text) and 298/1.2/94 to 298/6.2/94 (maps), Water Research Commission, Pretoria.

Midgley, J.J., Cowling, R.M., Seydack, A.W.H., van Wyk, G.F., 1997. Forest. In: Cowling, R.M., Richardson, D.M., Pierce, S.M. (Eds.), Vegetation of Southern Africa. Cambridge University Press, Cambridge, pp. 278-299.

Moll, E.J., McKenzie, B., McLachlan, D., 1980. A possible explanation for the lack of trees in the fynbos, Cape Province, South Africa. Biol. Conserv. 17, 221-228.

Nel, J., Bailey, C., van Wilgen, B., 1999. Management plan for the alien vegetation in the Sabie/Sand Catchment. Report No. ENV/S-C 99097, Division of Water, Environment and Forestry Technology, CSIR, Stellenbosch.

Ninham-Shand, 1996. First phase of the Plettenberg Bay coastal catchments study. Reports 1 to 12 of Report PK000/00/1996, Department of Water Affairs and Forestry, Pretoria.

O'Keeffe, J.H., Weeks, D.C., Fourie, A., Davies, B.R., 1996. A preimpoundment study of the Sabie-Sand River system, Mpumalanga with special reference to the predicted impacts on the Kruger National Park. Vol. 3. The effects of proposed impoundments and management recommendations. Report No. 294/1/96, Water Research Commission, Pretoria.

Olbrich, B.W., Hassan, R., 1999. A comparison of the economic efficiency of water use of plantations, irrigated sugarcane and sub-tropical fruits. A case study of the Crocodile River catchment, Mpumalanga Province. Report No. 666/1/99, Water Research Commission, Pretoria.

Olbrich, B.W., Poulter, A.G., 1997. Streamflow responses to clearing exotic vegetation from three sites located on the
Mpumalanga escarpement. Unnumbered Report, Division of Water, Environment and Forestry Technology, CSIR, Nelspruit.

Prinsloo, F.W., Scott, D.F., 1999. Streamflow responses to the clearing of alien invasive trees from riparian zones at three sites in the Western Cape Province. S. Afr. For. J. 185, 1-7.

Pysek, P., Prach, K., 1993. Plant invasions and the role of riparian habitats: a comparison of four species alien to central Europe. J. Biogeogr. 20, 413-420.

Richardson, D.M., 1998. Commercial forestry and agroforestry as sources of invasive alien trees and shrubs. In: Schei, J., Sandlund, O.T. (Eds.), Invasive Species and Biodiversity Management. Chapman \& Hall, London, pp. 237-257.

Richardson, D.M., Cowling, R.M., 1992. Why is mountain fynbos invadable and which species invade? In: van Wilgen, B.W., Richardson, D.M., Kruger, F.J., van Hensbergen, H.J. (Eds.), Fire in South African Mountain Fynbos: Species, community and ecosystem response in Swartboskloof. Springer, Heidelberg, pp. 161-181.

Richardson, D.M., van Wilgen, B.W., 1986. The effects of fire in felled Hakea sericea and natural fynbos and implications for weed control in mountain catchments. S. Afr. For. J. 139, 4-14.

Richardson, D.M., Macdonald, I.A.W., Holmes, P.M., Cowling, R.M., 1992. In: Cowling, R.M. (Ed.), Plant and Animal Invasions. The Ecology of Fynbos: Nutrients, Fire and Diversity. Oxford University Press, Cape Town, pp. 271-308.

Richardson, D.M., van Wilgen, B.W., Le Maitre, D.C., Higgins, K.B., Forsyth, G.G., 1994. A computer-based system for fire management in the mountains of the Cape Province, South Africa. Int. J. Wildland Fire 4, 17-32.

Russel, I.A., Rodgers, K.H., 1989. The distribution and composition of the fish communities in the major rivers of the Kruger national park. In: Proceedings of the South African Aquatic Sciences Symposium, Pretoria, pp. 281-288.

Schulze, R.E., McGee, O.S., 1978. Climatic indices and classifications in relation to the biogeography of southern Africa. In: Werger, M.J.A. (Ed.), Biogeography and Ecology of Southern Africa. Vol. 1. Dr. W. Junk Publishers, The Hague, pp. 19-52.

Schulze, R.E., Angus, G.R., Lynch, S.D., Smithers, J.C., 1995. ACRU: concepts and structure. Hydrology and agrohydrology: a text to accompany the ACRU 3.00 Agrohydrological modelling system. Report TT69/95, Water Research Commission, Pretoria.

Scott, D.F., 1993. The hydrological effects of fire in South African mountain catchments. J. Hydrol. 150, 409-432.

Scott, D.F., Lesch, W., 1995. The water yield gains from clearfelling riparian zone vegetation. In: Proceedings of the Seventh South African National Hydrological Symposium, Institute for Water Research, Grahamstown.

Scott, D.F., Van Wyk, D.B., 1990. The effects of wildfire on soil wettability and hydrological behaviour of an afforested catchment. J. Hydrol. 121, 239-256.

Scott, D.F., Van Wyk, D.B., 1992. The effects of fire on soil water repellency, catchment sediment yields and streamflow. In: van Wilgen, B.W., Richardson, D.M., Kruger, F.J., Hendsbergen, H.J. (Eds.), Fire in South African Mountain fynbos. Ecosystem Community and Species Response at Swartboskloof. Springer, Berlin, pp. 216-239. 
Scott, D.F., Le Maitre, D.C., van Wilgen, B.W., 1991. Problems relating to the fire site on Devils Peak and proposals toward their solution. Unpublished contract report to the City Engineer, Cape Town Municipality. CSIR Division of Forest Science and Technology, Pretoria.

Scott, D.F., Le Maitre, D.C., Fairbanks, D.H.K., 1998a. Forestry and streamflow reductions in South Africa. A reference system for assessing extent and distribution. Water SA 24, 187-199.

Scott, D.F., Versfeld, D.B., Lesch, W., 1998b. Erosion and sedimentation in relation to afforestation and fire in the Western Cape Province, South Africa. S. Afr. Geogr. J. 80, 52-59.

Scott, D.F., Prinsloo, F.W., Moses, G., 1999. Results of the afforested catchment experiments: range and variability of effects and the controlling variables. Paper presented at the 9th National Hydrology Symposium, University of the Western Cape, November 1999.

Schreiner, B., 1999. The challenges of water resources management in South Africa. Keynote address presented at the 9th National Hydrology Symposium, University of the Western Cape, November 1999.

Skellam, J.G., 1951. Random dispersal in theoretical populations. Biometrika 38, 196-218.

Thebaud, C., Debussche, M., 1991. Rapid invasion of Fraxinus ornus L. along the Herault River system in southern France: the importance of dispersal by water. J. Biogeogr. 18, 7-12.

Thompson, M.W., 1996. A standard land-cover classification scheme for remote sensing applications in South Africa. S. Afr. J. Sci. 92, 34-42.

Umgeni Water 1998a. Midmar dam catchment. Riparian zone rehabilitation study. Report M0638/1 prepared by MBB Consulting Engineers Inc. for Umgeni Water, Pietermaritzburg.

Umgeni Water 1998b. Upper Mvoti catchment. Riparian zone rehabilitation study. Report M0638/2 prepared by MBB Consulting Engineers Inc. for Umgeni Water, Pietermaritzburg.

Van der Zel, D.W., 1995. Accomplishments and dynamics of the South African afforestation permit system. S. Afr. For. J. 172, $49-58$.

Van Lill, W.S., Kruger, F.J., van Wyk, D.B., 1980. The effect of afforestation with Eucalyptus grandis Hill ex Maiden and Pinus patula Schlecht. Et. Cham. on streamflow from experimental catchments at Mokubalaan, Transvaal. J. Hydrol. 48, 107-118.

van Wilgen, B.W., Richardson, D.M., 1985. The effect of alien scrub invasion on vegetation structure and fire behaviour in
South African fynbos shrublands. J. Appl. Ecol. 22, 955966.

van Wilgen, B.W., Higgins, K.B., Bellstedt, D.U., 1990. The role of vegetation structure and fuel chemistry in excluding fire from forest patches in the fire-prone fynbos shrublands of South Africa. J. Ecol. 78, 210-222.

van Wilgen, B.W., Cowling, R.M., Burgers, C.J., 1996. Valuation of ecosystem services: a case study from the fynbos, South Africa. BioScience 46, 184-189.

van Wilgen, B.W., Little, P.R., Chapman, R.A., Gorgens, A.H.M., Willems, T., Marais, C., 1997. The sustainable development of water resources: History, financial costs, and benefits of alien plant control programmes. S. Afr. J. Sci. 93, 404-411.

van Wilgen, B.W., Cowling, R.M., Le Maitre, D.C., 1998. Ecosystem services, efficiency, sustainability and equity: South Africa's Working for Water programme. Trends Ecol. Evol. 13, 378.

van Wilgen, B.W., Van der heyden, F., Zimmermann, H.G., Magadlela, D., Willems, T., 2000. Big returns from small organisms: developing a strategy for the biological control of invasive alien plants in South Africa. S. Afr. J. Sci. 96, 148152.

Van Wyk, D.B., 1987. Some effects of afforestation on streamflow in the Western Cape Province, South Africa. Water SA 13, 3136.

Versfeld, D.B., Le Maitre, D.C., Chapman, R.A., 1998. Alien Invading Plants and Water Resources in South Africa: A Preliminary Assessment. Report TT99/98, Water Research Commission, Pretoria.

Vitousek, P.M., D'Antonio, C., Loope, L.L., Rejmanek, M., Westbrooks, R., 1997. Introduced species: a significant component of human-caused global change. N. Z. J. Ecol. 21, $1-16$.

Walmsley, R.D., Davies, B.R., 1991. An overview of water for the environment. Water SA 17, 67-76.

Weeks, D.C., O'Keeffe, J.H., Fourie, A., Davies, B.R., 1996. A preimpoundment study of the Sabie-Sand River system, Mpumalanga with special reference to the predicted impacts on the Kruger National Park. Vol. 1. The ecological status of the Sabie-Sand River system. Report No 294/1/96, Water Research Commission, Pretoria.

Working for Water, 1999. The Working for Water Programme 1998/99 Annual Report. Working for Water Programme, Department of Water Affairs and Forestry, Bellville. 